\title{
Primjena vanjskog ugovaranja u resoru obrane*
}

\section{Bernard Markušic **}

\author{
UDK $\quad 355.02: 331.533(497.5)$ \\ 355.02:351.712(497.5) \\ Review scientific paper / pregledni znanstveni rad \\ Received / primljeno: 16.11.2016. \\ Accepted / prihvaćeno: 15. 9.2017.
}

Primjena vanjskog ugovaranja (outsourcinga) u resoru obrane aktualan je trend u vođenje državne obrambene politike i relativno nov fenomen u javnom upravljanju. $U$ radu se analiziraju ekonomski i pravni aspekti vanjskog ugovaranja u resoru obrane i pokušava se odgovoriti na pitanja stvarne razine ekonomičnosti i efikasnosti takvog pristupa s jedne te pravne opravdanosti i mogućih implikacija za standarde demokracije s druge strane. Analiza počinje s općim pojmovnim određenjem vanjskog ugovaranja na skali javnoprivatnih partnerstava. Istražuje se praksa vanjskog ugovaranja primarno na primjeru SAD-a, počevši s tipologijom i kratkim povijesnim pregledom privatnog vojnog sektora. Nakon toga slijedi ispitivanje ekonomičnosti i efikasnosti vanjskog ugovaranja vojnih usluga s privatnim akterima.

* Radu je 2015. dodijeljena godišnja nagrada »Eugen Pusić« Instituta za javnu upravu u kategoriji najboljeg studentskog znanstvenog rada. This paper received the »Eugen Pusić « Award in the category of best student scientific papers by the Institute of Public Administration in Zagreb, Croatia.

** Bernard Markušić, student pete godine pravnog studija na Pravnom fakultetu Sveučilišta u Zagrebu (fifth year law student at the Faculty of Law, University of Zagreb, Croatia, e-mail: mark.bernard.cro@gmail.com) 
Pravna analiza podjednako je važna zbog neujednačenog i češće nepostojećeg pravnog okvira koji bi regulirao privatne vojne kompanije. Za primjer se uzima primarno SAD, ali dio pregleda posvećuje se i praksi primjene outsourcinga u britanskom i njemačkom modelu.

Ključne riječi: vanjsko ugovaranje, javno-privatna partnerstva, PMC, privatne vojne kompanije, UN, Document iz Montreuxa, outsourcing

\section{Uvod}

Vanjsko ugovaranje različitog spektra usluga s privatnim vojnim i zaštitarskim tvrtkama moderan je trend javno-privatne suradnje u resorima obrane ekonomski i vojno razvijenih država. U SAD-u ta je praksa prisutna već desetljećima, a države poput Rusije i Kine naglo otkrivaju prednosti diskretnog djelovanja takvog »modernog načina ratovanja«. Iz pojedinih novinskih članaka ${ }^{1}$ nameće se pozitivan stav o takvoj suradnji. Međutim, određena pitanja zahtijevaju dublju analizu i višu razinu kritičnosti, zbog čega je ovo istraživanje usmjereno prema otkrivanju odgovara na dva temeljna pitanja: Kolika je stvarna razina efektivnosti i ekonomičnosti privatnih kontraktora u usporedbi s konvencionalnom vojskom? Još važnije: Može li takva upotreba biti pravno opravdana i koje su moguće posljedice za standarde demokracije, ako ne i za strukture države i društva? S ciljem pronalaženja odgovora na navedena pitanja te shodno tome primjenjivosti u hrvatskom javnom upravljanju, prvo se analizira opće pojmovno određenje vanjskog ugovaranja na skali javno-privatnih partnerstava (JPP). Razlog tome je što vanjsko ugovaranje usluga s privatnim vojnim i zaštitarskim kompanijama pokriva samo dio spektra javno-privatne suradnje. $U$ tom kontekstu, važno je odijeliti već spomenuti model od infrastrukturnih javno-privatnih partnerstava značajnih za izgradnju, modernizaciju i ekonomičnost održavanja vojne infrastrukture.

U nastavku rada istraživanje se neće ograničiti na domaći kontekst, već se analizira praksa korištenja privatnih vojnih kompanija na primjeru SADa. Razlog tome je što je takva praksa skoro nepostojeća u Republici Hr-

1 Primjerice: »Država može vojsku outsourcati, obvezni vojni rok nema smisla... Dugo je vladala dogma o ekskluzivnom pravu države na legitimnu primjenu sile. Paradigma se u svijetu mijenja, što bismo i mi trebali pratiti.« - Daniel Hinšt, Komentar Jutarnjeg lista, 13. travnja 2015. 
vatskoj, a sa druge strane, de lege lata, osnivanje takvih kompanija nije dopušteno u Hrvatskoj. Radi traženja odgovora na temeljna pitanja ovog rada prvo se polazi od tipologije različitih oblika privatnih poduzeća koja ispunjavaju karakteristike privatnih vojnih kompanija. Analiza se nastavlja kratkim povijesnim pregledom nastanka modernih vojnih kompanija. Nakon toga slijedi ispitivanje ekonomičnosti i efikasnosti vanjskog ugovaranja vojnih usluga s privatnim akterima. Važnost povijesno-funkcionalnog pregleda ogleda se u mogućnosti prepoznavanja pogrešaka i nedostataka, pa čak i potencijalnih negativnih implikacija nastalih korištenjem privatnih aktera u resoru obrane. Pravna analiza podjednako je važna zbog neujednačenog i češće nepostojećeg pravnog okvira koji bi regulirao privatne vojne kompanije. Za primjer se uzima primarno SAD, kao država u kojoj je većina takvih kompanija registrirana, ali dio pregleda posvećuje se i relativno nedavno prihvaćenoj praksi primjene modela JPP-a u resoru obrane država članica EU-a, odnosno britanskom i njemačkom modelu. Poseban osvrt dan je i na primjere nedavnih presuda američkih sudova, obradu i komentare statističkih podataka relevantnih međunarodnih i državnih organizacija, a provedeno je i istraživanje u obliku intervjua. ${ }^{2}$

\section{Pojmovno određenje vanjskog ugovaranja na skali javno-privatnih partnerstava}

Vanjsko ugovaranje (outsourcing) u javnoj upravi predstavlja ugovorni odnos kojim se prenosi dio ili čitav radni proces pružanja javnih usluga i/ ili proizvodnje javnih dobara vanjskim partnerima privatnog sektora koji onda izvršavaju te poslove umjesto javne uprave. Cilj koji se želi postići takvim pristupom pružanju javnih usluga jest smanjenje broja uključenih u radne procese uz zahtjev istovremenog povećanja efikasnosti (Poutvaara, 2004). Osim putem outsourcinga, to se postiže različitim menadžerskim tehnikama upravljanja te partnerskim ugovornim i institucionalnim odnosima između javnih vlasti i privatnih aktera. Stoga, radi potpunog razumijevanja važno je pojmovno određenje javno-privatnih partnerstava kao nadređenog pojma vanjskom ugovaranju.

Javno-privatna partnerstva (Public Private Partnership, JPP) predstavljaju pothvate suradnje između tijela javne vlasti s privatnim sektorom, neovi-

${ }^{2}$ Korišteni iskazi i izvješća citirani u radu neslužbeni su autorov prijevod rada s ciljem održavanja hrvatskog jezika kao jedinog korištenog u glavnom tekstu rada. 
sno o tome je li riječ o razini središnje vlasti ili lokalne zajednice, s ciljem zadovoljavanja neke javne potrebe. Largo sensu, oblicima JPP-a smatra se »skupina zajedničkib inicijativa javnog sektora te privatnog profitnog $i$ neprofitnog sektora u kojima svaki subjekt pridonosi odredene resurse $i$ sudjeluje u planiranju $i$ odlučivanju. « Stricto sensu, JPP-om definiraju se »kooperativni pothvati u sklopu kojih javni i privatni sektori udružuju resurse i stručna znanja kako bi kroz prikladne alokacije resursa, rizika i nagrada zadovoljili neku javnu potrebu.« (Gulija, 2004, str. 1). Takav pristup omogućio je privatnom sektoru djelomično ili potpuno ugovorno preuzimanje pružanja javnih usluga i dobara koje su tradicionalno osiguravale javne službe (prema terminologiji acquis communautaire - službe od općeg interesa). Nastavljajući se na stav EU-a, izražen u Zelenoj knjizi o javno-pravnim partnerstvima (EC, 2004), istaknuto je nepostojanje opće važeće definicije JPP-a. Utemeljenje na općenitosti odnosa suradnje između javnih tijela i privatnih poduzetnika rezultiralo je neslaganjima oko toga koje oblike suradnje možemo svesti pod pojam JPP-a.

\subsection{Klasifikacija modela suradnje javnog i privatnog sektora}

Izostanak općevažeće definicije JPP-a posljedično je doveo do prijepora oko toga koji modeli suradnje ulaze u taj spektar, a koji se nalaze izvan njega. Klasifikacija u sljedećoj tablici rezultat je sinteze smjernica EU-a (v. amplius EC, 2003 Guideliness for Succesfull Public-Private Partnerships, 2003) i Svjetske banke (v. amplius Delmon, 2010) pojmovno nadopunjena stručnom literaturom stranih i domaćih autora.

Tablica 1 razvrstava skupine ovisno o stupnju uključenosti javnog i privatnog sektora te alokacije rizika između njih. Primjećuje se da prema tom kriteriju spektar JPP-a zauzima poziciju između dva pola - klasičnog državnog financiranja i potpune privatizacije javnih dobara. To jasno upućuje na glavne karakteristike JPP-a, a to je odnos utemeljen na načelnoj ravnopravnosti ugovornih stranaka i dugoročna suradnja.

Terminologija iz tablice 1 uobičajena je terminologija modela JPP-a utemeljena na engleskim kraticama i na taj način jasno opisuje koje funkcije pojedini ugovori pokrivaju. Dvije temeljne vrste modela JPP-a su vanjsko ugovaranje (outsourcing) te infrastrukturna javno-privatna partnerstva koji se dalje dijele u svoje podmodele. 
Tablica 1. Skala javno-privatne suradnje prema stupnju uključenosti $i$ razini rizika

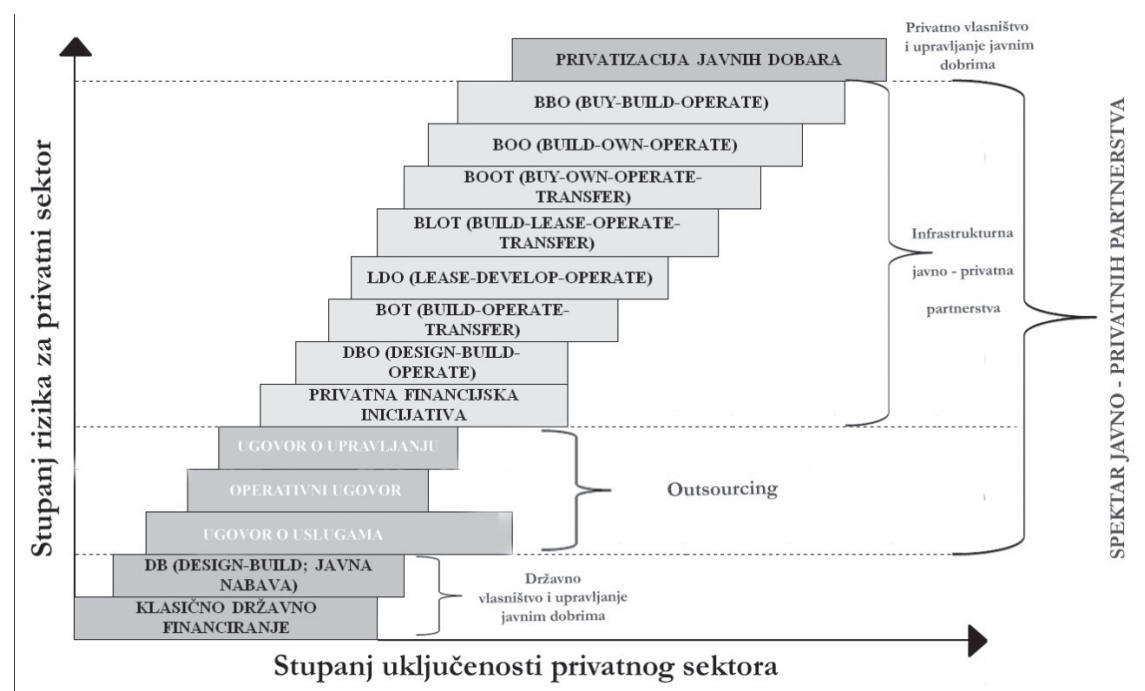

Izvor: Autor.

\subsubsection{Vanjsko ugovaranje kao model javno-privatnih partnerstva}

Opća definicija vanjskog ugovaranja iznesena je na početku rada. Vezano za njegove podmodele treba naglasiti da svi dijele njegove temeljne karakteristike. Prema Smjernicama EU-a (EC, 2003, str. 23) i stručnim analizama modela JPP-a (Cheung, 2009, str. 329), glavnim podmodelima podugovaranja smatraju se ugovori o uslugama, operativni ugovori i ugovori o upravljanju.

Ugovori o uslugama (Service Contracts) smatraju se klasičnim modelom outsourcinga. Javne agencije putem njih ulaze u ugovorne odnose s privatnim subjektima radi izvršenja određenih zadataka. Posebno su korisni za eksterno obavljanje pojedinih javnih usluga čiji široki spektar varira od zbrinjavanja otpada, naplate cestarina, čišćenja, održavanja tehničke opreme do vanjskog ugovaranja zaštitarskih usluga s privatnim vojnim i zaštitarskim tvrtkama. Odabrani privatni partner obično se bira javnim natječajem i sklapa ugovor s javnim vlastima čije trajanje može iznositi nekoliko mjeseci do nekoliko godina. Iako je ugovorno razdoblje kraćeg trajanja nego kod infrastrukturnih JPP-a, praksa pokazuje da se ugovori obnavljaju te tako dovode do produžene javno-privatne suradnje (EC, 2003, str. 20). Najvažnije obilježje ugovora o uslugama jest da se odgovornost za 
infrastrukturne investicije i odluka o njima zadržava u domeni javne vlasti. Uza sve operativne prednosti koje takvi ugovori nude, njihov je nedostatak što ne mogu utjecati na neefikasnost proizašlu iz loše organizacije i upravljanja u javnom sektoru. Kao opcija za rješavanje neefikasnosti te prirode, uz infrastrukturne JPP, postoji opcija vanjskog ugovaranja vođenja i operative javnog sektora.

Operativnim (Operation Contracts) i upravljačkim (Management Contracts) ugovorima javne agencije prenose odgovornost za operativno i organizacijsko vođenje javne infrastrukture privatnim subjektima. Za oba su podmodela karakteristični postupak odabira ponuđača i trajanje ugovora koji mutatis mutandis odgovaraju karakteristikama ugovora o uslugama. Prednost ugovora o upravljanju tehnička je ekspertiza privatnog sektora u organizacijskom vođenju i upravljanju ljudskim potencijalima. Kvalitetna praktična primjena takvog ugovora omogućuje proračunske uštede. Operativnim ugovorima se pak istodobno prenosi odgovornost i za upravljanje i održavanje javne infrastrukture na nekog ili neke privatne subjekte. Po svojoj prirodi takvi su ugovori izrazito kompleksni i smatra se da u praksi dovode do poticanja veće efikasnosti i tehnološke modernizacije.

Razlika između dvaju navedenih podmodela u usporedbi s ugovorima o uslugama je u načinu plaćanja. Naime, plaćanje može biti fiksno određeno kao kod vanjskog ugovaranja usluga, ali se u praksi češće temelji na procjeni radnog učinka gdje privatnik koji ispuni ili unaprijedi standarde kvalitete i dostupnosti usluga (specificiranih ugovorom) biva nagrađen značajnom novčanom nagradom. Operativni i upravljački ugovori dijele karakteristike s podmodelima infrastrukturnih JPP-a, ali se iz važnog razloga ne mogu smatrati njihovim podmodelima. Taj je razlog što svi oblici podugovaranja dijele karakteristiku da odgovornost za infrastrukturne investicije i ovlast donošenja takvih odluka ostaje u domeni autoriteta javne vlasti. Slijedom navedenog, operativne i upravljačke ugovore možemo smatrati svojevrsnom »test-fazom « pravne regulacije javno-privatnih partnerstva s jedne te poticanja snažnijeg sudjelovanja privatnog sektora u budućim projektima s druge strane. Kao podmodel, EK preporučuje njihovu praktičnu primjenu tranzicijskim državama kojima je sustav JPPa novina u javnom upravljanju te u javnim sektorima koji su tek počeli s privatizacijom (EC, 2003, str. 21).

Vanjsko ugovaranje kao model JPP-a u resoru obrane obično vodi u suradnju javnih vlasti i privatnih vojnih ili zaštitarskih kompanija u ulozi privatnih partnera. Privatne vojne kompanije poslovne su organizacije koje nude specijalizirane usluge vezane uz rat i oružane konflikte. Taj spektar 
obuhvaća usluge od nabave i održavanja oružja i vojne opreme, obuke i novačenja, operativne i tehničke podrške, prikupljanja obavještajnih podataka, pa sve do strateškog planiranja i uključivanja u borbene operacije.

\section{Analiza razvoja i praktične upotrebe privatnih vojnih kompanija u resoru obrane}

Moderni privatni vojni sektor nastaje početkom 1990-ih, a rezultat je spoja triju neovisnih procesa: ekonomsko-političke transformacije koja počinje završetkom ere hladnog rata, promjene prirode ratovanja (koja kao asimetrično ratovanje današnjice često pomiče liniju između civila i vojnika) i već spomenutog globalnog trenda pristupanja privatizaciji i različitim modelima JPP-a u javnom upravljanju.

Sve države unutar kojih su privatne vojne kompanije registrirane i čije usluge koriste obilježene su slabom, pa nekad i nepostojećom zakonskom regulativom kojom bi se regulirala njihova aktivnost. Posebni problemi nastaju kada se usluge pružaju u trećim, inozemnim državama. Nedostatak adekvatnog nadzora logična je posljedica i jasno upozorava na važnost pitanja privatnih vojnih kompanija u odnosu na javnu upravu.

Međutim, uspješno reguliranje podrazumijeva prepoznavanje problema koji nastaju kao rezultat pravnih praznina. Poznata je praksa da vlade suverenih država danas koriste privatne vojne kompanije da zaobiđu prepreke koje im nameću institucionalni nadzorni mehanizmi (npr. zakonski regulirano ograničenje broja vojnika raspoređenih u inozemnim državama). U mnogim državama privatne vojne kompanije nisu obvezne otkrivati opseg svojih aktivnosti niti detalje u vezi sa svojim troškovima. Jedan od najvećih problema jest što zaposleni u privatnim vojnim kompanijama ne podliježu vojnoj disciplini niti su obučeni da obavljaju operacije u skladu s postojećim pravom o oružanim sukobima. Pored toga, privatne vojne kompanije mogu lako raspustiti svoje operacije, čime mogu otežati potragu za svojim osobljem u slučaju povrede zakona.

\subsection{Tipologija privatnog vojnog sektora}

Privatne vojne kompanije (private military companies, PMCs) koje se nazivaju još i privatnim vojnim poduzećima (private military firms, PMFs) te privatne zaštitarske kompanije (private security companies, PSCs) dva su 
glavna tipa organizacija u privatnom vojnom sektoru. Pored njih, poznajemo još i tradicionalne kompanije za logističku i tehničku podršku koje u pravilu ne podrazumijevaju davanje usluga vojne i zaštitarske prirode.

Tablica 2. Tipologija privatnog vojnog sektora

\begin{tabular}{|c|c|c|c|}
\hline & PRIVATNI & VOJNI & SEKTOR \\
\hline \begin{tabular}{|l} 
VRSTA \\
KONTRAKTORA
\end{tabular} & $\begin{array}{l}\text { Tradicionalne } \\
\text { kompanije za } \\
\text { tehnničku i logističku } \\
\text { podř̌ku }\end{array}$ & $\begin{array}{l}\text { Privatne zaštitarske } \\
\text { kompanije (PSCs) }\end{array}$ & $\begin{array}{l}\text { Privatne vojne } \\
\text { kompanije (PMCs) }\end{array}$ \\
\hline $\begin{array}{l}\text { VRSTA } \\
\text { KLIJENATA }\end{array}$ & $\begin{array}{l}\text { Vlade, NGOs, } \\
\text { obavještajne službe, } \\
\text { druge kompanije itd. }\end{array}$ & $\begin{array}{l}\text { Druge kompanije, } \\
\text { obavještajne službe, } \\
\text { NGOs }\end{array}$ & $\begin{array}{l}\text { Vlade i obavještajne } \\
\text { agencije }\end{array}$ \\
\hline CILJ USLUGE & $\begin{array}{l}\text { Logistička i tehnička } \\
\text { podrška }\end{array}$ & Zaštitarske usluge & Strateška sigurnost \\
\hline $\begin{array}{l}\text { PRIMJER } \\
\text { USLUGE }\end{array}$ & $\begin{array}{l}\text { Razminiravanje, } \\
\text { logistika i opskrba, } \\
\text { »risk« konzalting, } \\
\text { strateški transport }\end{array}$ & $\begin{array}{l}\text { Zaštita objekata, } \\
\text { konvoja, pojedinaca }\end{array}$ & $\begin{array}{l}\text { Vojni trening, } \\
\text { obavještajne usluge, } \\
\text { policijski trening, } \\
\text { reforme sektora }\end{array}$ \\
\hline $\begin{array}{l}\text { PRIMJER } \\
\text { KOMPANIJE }\end{array}$ & $\begin{array}{l}\text { Evergreen, ICI of } \\
\text { Oregon, KBR, MSS, } \\
\text { PAE }\end{array}$ & $\begin{array}{l}\text { ArmorGroup, } \\
\text { Blackwater, Hart, } \\
\text { SOC - SMG, Triple } \\
\text { Canopy }\end{array}$ & $\begin{array}{l}\text { DynCorp, MPRI, } \\
\text { Northrop - } \\
\text { Grumman }\end{array}$ \\
\hline \multicolumn{4}{|c|}{$\begin{array}{l}\text { Kao što tablica } 2 \text { pokazuje, usluge koje nude PMCs slične su onima koje } \\
\text { obavljaju vladini organi unutrašnjih poslova ili redovna vojska, samo su } \\
\text { uglavnom manjeg opsega. Usluge koje nude PSCs uglavnom se svode na } \\
\text { zaštitarske usluge na neprijateljskom teritoriju. Važno je napomenuti da } \\
\text { navedena tipologija predstavlja teoretsko razlikovanje budući da mnoge } \\
\text { PMCs nude i usluge iz sektora PSCs, i obratno. Linija razgraničenja nji- } \\
\text { hova djelokruga postaje sve mutnija kako se profit takvih organizacija po- } \\
\text { većava jer veći profit znači i recipročno povećanje broja osoblja i usluga } \\
\text { takvim privatnim kompanijama. Osoblje takvih privatnih kompanija naziva } \\
\text { se kontraktorima, iako radne dužnosti mnogih od njih možemo prepoznati } \\
\text { kao ulogu plaćenika u oružanim sukobima. Praktično, oni svojim uslugama } \\
\text { stvarno nekad prelaze liniju i mogli bi se nazvati plaćenicima. Drugačija ter- }\end{array}$} \\
\hline
\end{tabular}


minologija koristi se između ostaloga s ciljem udovoljenja zahtjevima međunarodnih konvencija koje usluge takvih pojedinaca zabranjuju.

Najvažniji međunarodnopravni dokument posvećen tome je Međunarodna konvencija UN-a protiv novačenja, korištenja, plaćanja i osposobljavanja plaćenika (NN MU-12/99). Konvencija definira pojam plaćenika u čl. 1. i 2. Jedna od potpisnica te Konvencije je i Republika Hrvatska. Međutim, nije bez razloga što su sve privatne vojne kompanije registrirane u SAD-u i Ujedinjenom Kraljevstvu (UK), jer su te dvije države jedne od rijetkih koje nisu potpisale Konvenciju. Pažljivom analizom članaka Konvencije može se primijetiti da se pojmom plaćenika standardno smatraju sudionici u oružanom sukobu motivirani isključivo vlastitom dobiti. Takva definicija zaslužuje kritiku zbog nedovoljne preciznosti jer težište stavlja na motivaciju za djelovanje koju je teško identificirati, umjesto na same postupke. $\mathrm{Na}$ primjer, mnogi američki sigurnosni kontraktori pod ugovorom tvrde da rade podjednako iz patriotizma koliko iz financijske koristi. Mnoge kompanije specijalizirane za zaštitu osoba i imovine naspram kompanija koje nude usluge isključivo vojne prirode imaju tendenciju stavljati naglasak na uslugu civilne zaštite. U praksi, teško je uočiti razliku između borbenih i zaštitnih uloga kada ta zaštita utječe na ishod konflikta. Nadalje, najveću opasnost predstavlja izrazito manjkavo i nedovoljno dobro regulirano zakonodavstvo o privatnom vojnom sektoru. Veličina privatnih vojnih kompanija varira od malih konzultantskih kompanija do ogromnih transnacionalnih kompanija. Iako su se prvotno konzultantske kompanije pojavile još tijekom Drugog svjetskog rata, geopolitičke promjene i rekonstrukcija vojnih snaga u mnogim državama nakon hladnog rata potaknule su razvoj na do tada neviđenu razinu u privatnom vojnom sektoru. Danas postoji više od 150 kompanija koje svoje usluge nude u preko 50 država (Singer, 2005).

\subsubsection{Tržište za privatni vojni sektor}

Klijenti ugovora u privatnom vojnom sektoru nisu samo vlade suverenih država, već i međunarodne institucije (poglavito UN), multinacionalne kompanije i pojedinci koji traže takve vojne i zaštitarske usluge. Klijente u privatnom vojnom sektoru možemo podijeliti u tri kategorije s obzirom na svrhu sklopljenih ugovora.

Prvu kategoriju čine vlade suverenih država. Kada je o njima riječ, privatne vojne kompanije najčešće se koriste radi kompenzacije manjka domaćih (ljudskih ili tehnoloških) kapaciteta. Privatne vojne kompanije danas barataju ogromnim kapitalom koji ulažu u razvoj pojedinih visokotehnoloških rješenja, za koja države nemaju dovoljno sredstava da ih same razvijaju 
ili obučavaju osoblje za korištenje takvim tehnologijama. U nekim slučajevima privatne vojne kompanije čak zamjenjuju nepostojeće kapacitete. Drugu kategoriju čine svi ostali navedeni korisnici usluga (osim pojedinaca). Oni koriste usluge privatnog vojnog sektora da im se omogući rad u opasnim sredinama. Privatne vojne kompanije već su dugi niz godina sastavni dio mirovnih misija po cijelom svijetu (Franke \& Dorff, 2013). Treću kategoriju čine pojedinci i grupe koji se ponekad koriste privatnim vojnim kompanijama za podmukle ciljeve kao što su državni prevrati ili štićenje nezakonitih radnji (Singer, 2008).

\subsection{Povijesni pregled razvoja privatnog vojnog sektora}

Involviranost privatnih poduzeća u resoru obrane duga je tradicija u SADu, pa i mnogim drugim državama. Takve usluge podrazumijevale su transport, održavanje opreme, opskrbu vojske i slično. Širenjem opsega usluga razvija se moderni privatni vojni sektor, koji nastaje iz redovnih vojski, i to završetkom hladnog rata. Naime, njegovim završetkom se smanjuje broj vojnika u konvencionalnim vojskama diljem svijeta i rasprodaje se oružje bivšeg SSSR-a državama i privatnim firmama. U tom periodu vojne se kompanije prvi put mogu opskrbiti sofisticiranim oružjem za malu cijenu i učiniti svoje usluge jedinstvenima raznim ponuđačima. U tome smislu govorimo o tome da privatne kompanije svoje usluge ne ograničavaju više samo na konzultantske usluge i logističku te tehničku podršku, već se izravno uključuju u oružane sukobe (Baum \& McGahan, 2009, str. 22).

Važno je spomenuti da od Francuske revolucije pa sve do sredine prošlog stoljeća ne postoji profesija privatnih plaćenika na području Europe. Promjena paradigme počinje procesom dekolonizacije. Prvi poslodavci nisu bile države i međunarodne organizacije, već privatne firme koje su imale namjeru zadržati pravo eksploatacije prirodnih resursa. Poglavito je tu riječ o Africi i rudnicima dijamanata. U afričkoj povijesti beskrupulozni plaćenici koji su radili za privatne kompanije često se koriste kao sinonim za južnoafrički apartheid (Singer, 2008, str. 32). Međutim, korištenje civilnih kontraktora od država i međunarodnih organizacija prvi se put manifestiralo i dovelo do eksponencijalne ekspanzije tržišta privatnih vojnih usluga za vrijeme oružanih sukoba na području bivše Jugoslavije te tijekom građanskog rata u Sijera Leoneu. Predmet detaljnije analize u nastavku bit će tri faze oružanih sukoba na području država bivše Jugoslavije kao značajnih etapa u razvoju modernog poimanja vanjskog ugovaranja vojnih usluga. Građanski rat u Sijera Leoneu analizira se u sklopu cost- 
benefit analize u nastavku. Zamjetna je i uloga $\mathrm{UN}$-a u raznim mirovnim misijama sa svrhama stabilizacije određenih regija.

\subsubsection{Važnost oružanih sukoba na području bivše Jugoslavije za ekspanziju privatnog vojnog tržišta}

Ključan trenutak u institucionaliziranju uloge privatnih vojnih kompanija kao integralnog dijela modernog ratovanja predstavljaju građanski rat u Sijera Leoneu te oružani sukobi na području država bivše Jugoslavije. Kod potonjih je riječ o tri faze tog oružanog sukoba: Domovinski rat na području RH, postratna obnova u BiH te intervencija NATO-a na području Kosova. Godine 1994., nakon inicijalnog proboja snaga Jugoslavenske narodne armije (JNA) i okupacije dijela teritorija RH, linije oružanog sukoba svojevrsno su se konsolidirale. Hrvatska vojska u to vrijeme bila je slabije opremljena i manjeg brojčanog kapaciteta od snaga JNA. Situacija se iznenada preokrenula akcijom »Oluja« iza koje je, prema ne tako davnoj presudi iz SAD-a, dobrim dijelom stajala privatna vojna kompanija Military Professional Resources Incorporated (MPRI).

Naime, 24. ožujka 1994., tadašnji hrvatski ministar obrane Gojko Šušak odlazi u posjet SAD-u s ciljem traženja vojne pomoći. U upućenom apelu navedenog ministra vlada SAD-a prepoznala je u RH potencijalnog saveznika u izrazito nestabilnoj regiji. Problem je bio u tome što je SAD bio onemogućen u direktnom pružanju vojne pomoći RH zbog embarga UN-a koji je zabranjivao bilo kakav aspekt vojne pomoći entitetima raspadnute Jugoslavije. Visoko rangirani službenici Pentagona vidjeli su način »zaobilaženja« embarga u upućivanju tadašnje vlade RH privatnoj vojnoj kompaniji sa sjedištem u saveznoj državi Virginiji - kompaniji Military Professional Resources Incorporated (MPRI). Međutim, embargo se odnosio i na privatne entitete, pa iz tog razloga nije bilo dopušteno izravno pružanje usluga vojnog planiranja, obavještajnih usluga ili savjeta vezanih uz taktiku i strategiju ratovanja hrvatskim oružanim snagama. MPRI-ju bilo je dopušteno samo pružanje obuke u područjima koja nisu direktno povezana s ratovanjem, kao što su jačanje vještina upravljanja u vojsci te seminara o ulozi vojske u demokratskom društvu (Gaul, 1998, str. 1489). MPRI kao kompanija priznaje pružanje potonjih usluga što je dalo odgovor na pitanje kako su oružane snage RH u tako kratkom roku prošle transformaciju u modernu vojsku koja po svojim karakteristikama ratovanja odgovara modelu koji primjenjuje NATO (Singer, 2008, str. 5). U narednom periodu, pojedini zaposlenici MPRI-ja ponosno su izjavljivali koliko je bila ključna njihova uloga u operaciji »Oluja«. Ipak, implicitno prizna- 
nje širokog spektra usluga vojnog planiranja i obuke časnika oružanih snaga RH od kompanije MPRI pokazalo se tek presudom Genocide Victims of Krajina v. L-3 Communications Corp. and MPRI Inc. (10-cv-05197). U tom slučaju, izbjeglice sa područja SAO Krajine tužile su MPRI za pomaganje hrvatskim oružanim snagama za počinjenje genocida. MPRI se odlučio nagoditi s tužiteljima te su pristali na isplatu materijalne kompenzacije u iznosu od 1,4 milijuna dolara. ${ }^{3}$ Tužitelji su temeljili svoju tužbu na zakonu Alien Tort Claims Act of 1789 ( 28 U.S.C. 1350) koji se od 1980-ih prošlog stoljeća tumači tako da strani državljani imaju pravo na zahtjev za pravnom zaštitom i materijalnom kompenzacijom za povredu ljudskih prava počinjenu izvan SAD-a. Između ostalog, u dokaznoj građi slučaja nalazilo se i pismo korespondencije između generala Janka Bobetka i predstavnika MPRI-ja.

Važnu ulogu privatnih kontraktora u Domovinskom ratu nije prepoznala i koristila samo Republika Hrvatska, već i snage JNA. JNA se koristila ruskim privatnim vojnim kompanijama i, za razliku od $\mathrm{RH}$, uglavnom za usluge koje su uključivale direktno uključivanje u oružane sukobe. Procjenjuje se da je oko 2.000 ruskih kontraktora radilo za snage JNA (Singer, 2008, str. 37). Međutim, tadašnje ruske privatne vojne kompanije te prateće osoblje nisu se mogli nositi s efektivnošću američkih i britanskih privatnih kompanija čije su osoblje mahom bili bivši specijalci i umirovljeni generali. Operacija »Oluja« dokaz je efikasnosti usluga privatnih kontraktora u očuvanju teritorijalnog suvereniteta i demokratskog poretka. S druge strane, ta je operacija afirmirala važnost privatnih vojnih kompanija u sličnim kriznim situacijama te je pomogla u prepoznavanju prednosti upotrebe takvih kontraktora u međunarodnim mirovnim misijama.

Promatrači UN-a bili su zapanjeni sofisticiranom koordinacijom oklopnih vozila, zračne podrške i pješadije te su operaciju »Oluja « opisali kao »operaciju prema vojnom priručniku NATO. Izjavili su: tko god da je planirao napad, morao je imati prosjek ocjena $A+$ na nekoj od vojnib akademija NATO-a« (Singer, 2008, str. 5). Zanimljiva je izjava jednog UN-ovog promatrača o stvarnoj ulozi i ugovorenim uslugama MPRI-ja: »Hrvati su napravili super posao u koordiniranju oklopnib vozila, artiljerije i pješaštva. To nije nešto što

3 Tužitelji su inicijalno tužili zbog počinjenja međunarodnog kaznenog djela genocida te su tražili naknadu materijalne štete u iznosu od 10,4 milijarde dolara u 2010. Sud je u nastavku postupka odbacio dio tužbe koji se odnosio na počinjenje kaznenog djela zbog stvarne nenadležnosti, ali je prihvatio dio tužbe koji se odnosio na odštetu za uništenu imovinu. Spor je okončan nagodbom u kojoj je MPRI pristao na isplatu 1,4 milijuna dolara u vidu humanitarne pomoći Srbima iz tzv. SAO Krajine. (V. amplius http://www.dnevno.hr/vijesti/hrvatska/ krajiski-srbi-zbog-oluje-dobili-1-4-milijuna-odstete-isto-sada-traze-i-srbi-iz-bih-978167/) 
se može naučiti na seminarima o vrijednostima demokratskog društva.« (Gaul, 1998, str. 1494).

Zaključno, najvažniji doprinos MPRI-ja bio je okončanje oružanog sukoba. Nakon pet godina krvavog rata, Srbija je konačno pristupila pregovaračkom stolu. Zanimljivo je da su Bošnjaci svoj pristanak i potpis prilikom potpisivanja Daytonskog sporazuma uvjetovali primanjem pomoći iste kompanije koja je pomogla $\mathrm{RH}$ u razdoblju postratne obnove. MPRI je prirodom stvari dobio nov ugovor i bio je sastavnim dijelom UN-ove mirovne misije UNMIBH. Ipak, što se tiče privatnog vojnog sektora, puno važniju ulogu u toj mirovnoj misiji imala je kompanija DynCorp koja je bila zadužena za obuku i nadzor lokalnih policijskih službenika (Singer, 2008).

Sljedeći korak u ekspanziji tržišta privatnih vojnih usluga bila je mirovna misija KFOR (Kosovo Force) na području Kosova. UN, predvođen jakom američkom inicijativom te u strahu od novog genocida, odlučuje se na direktnu intervenciju. Godine 1999. NATO otpočinje sa zračnim napadima na Srbiju kako bi prisilio tadašnjeg predsjednika Slobodana Miloševića na početak mirovnih pregovora. Međutim, SAD je bio suočen s internim problemima. Iako je bila riječ o plemenitom cilju, SAD je već bio uključen u previše mirovnih misija, a javnost je bila protiv korištenja rezervnih snaga za potrebe izgradnje skloništa za stotine tisuća izbjeglica s Kosova. Kako bi se uključio u rješavanje humanitarne krize bez upotrebe rezervnih snaga, SAD se okrenuo privatnom sektoru. Kao privatni partner zadužen za izgradnju skloništa odabrana je kompanija Brown and Root Services. Osim što je odabrani privatni partner uspio izgraditi infrastrukturu za privremeni smještaj izbjeglica, pokazao se iznimno korisnim i u opskrbi regionalnih američkih postrojbi, izgradnji vojnih kompleksa te održavanju vojnih vozila i vojnih sustava. Riječima generala Dennisa Reimera: »Operacija na Kosovu je priča o uspjebu, a kompanija Brown and Root tu je odigrala ključnu ulogu« (Singer, 2008, str. 6).

\subsubsection{Pravno reguliranje statusa civilnib kontraktora nakon incidenta u Bagdadu}

U novije vrijeme svjedočimo potrebi detaljnijeg reguliranja šireg spektra vanjskog ugovaranja vojnih usluga na međunarodnom planu. Oružane sukobe na području raspadnute Jugoslavije možemo smatrati svojevrsnim eksperimentom koji je upozorio na manjak regulativnog okvira privatnih vojnih kompanija. Rezultat su bile različite afere i de facto apsolutni kazneni procesni imunitet kontraktora, koji nisu mogli biti kazneno procesuirani zato što $\mathrm{BiH}$, a ni $\mathrm{SAD}$ (u kojima je većina takvih kompanija registrirana) 
nisu nad njima imali jurisdikciju. Ta pravna »praznina« riješena je tek pred sam kraj UNMIBH-a (United Nations Mision in Bosnia and Herzegovina), odnosno u studenom 2000. kada je američki Kongres izglasao Military Extraterritorial Jurisdiction Act of 2000 (MEJA) (Markušić, 2014).

Vojna intervencija u Iraku bila je svojevrstan pomak u spektru i intenzitetu korištenja privatnika za potrebe obrambene politike - tada se prvi put podugovaraju usluge zaštite diplomatskog osoblja i civilnog osoblja za pružanje vojne podrške. Ispostavilo se da kompanije, kao što je tada najvažniji kontraktor Blackwater, ne ulaze u okvir tog zakona zato što MEJA nije predviđao civilne kontraktore u ulozi borca. Naime, do ožujka 2013., privatni kontraktori čine $62 \%$ ukupnog broja pripadnika oružanih snaga, od čega je čak 15\% bilo angažirano za zaštitarske usluge. Slične brojke su i na području Iraka. Naime, asimetrično ratovanje zahtijeva promjenu načina vođenja državne oružane sile te se na primjeru SAD-a omjer nacionalnih postrojbi naspram civilnih kontraktora od inicijalnog omjera 10:1 u sljedećih 20 godina okrenuo u korist civilnih kontraktora do omjera 1:6 (Pelton, 2007). Opasnosti takvog pristupa postale su jasne tek kada su se počela pojavljivati svjedočanstva o kršenju ljudskih prava od privatnih kontraktora. Konkretno, pojavile su se optužbe za mučenje i nasilje nad lokalnim stanovništvom. Prva presuda za počinjenje teških kaznenih djela donesena je tek u travnju 2015. (Hsu \& St. Martin, 2015). Naime, zaposlenici kompanije Blackwater bez povoda su tijekom vožnje po središtu Bagdada 2007, točnije po trgu Nisoor, otvorili vatru na civile i pritom snimali svoje radnje. Ubijeno je 17 civila, a 24 ih je ranjeno (Human Rights First, 2011, str. 1). Sličan slučaj bio je i onaj Raymonda Davisa, kontraktora CIA-e (Central Intelligence Agency) koji je optužen za teško ubojstvo dvoje civila u Pakistanu 2011.

Ubojstva na trgu Nisoor 2007. probudila su interes javnosti pa je pokrenuta politička inicijativa za pravnim reguliranjem položaja kontraktora čija je uloga jednaka ulozi vojnika. Obitelji žrtava pokrenule su postupak pred sudom SAD-a na istim temeljima kao i izbjeglice iz SAO Krajine. Riječ je o slučaju (07-1831-) Estate of Himoud Saed Atban et al. v. Blackwater USA et al. Slučaj je riješen 2012. nagodbom, a konkretni detalji te nagodbe nisu dostupni javnosti. U međuvremenu donesen je zakon Civilian Extraterritorial Jurisdiction Act of 2011 (CEJA) kojim je odgovornost takvih kontraktora regulirana. Iako je većina vojnih kompanija registrirana u SAD-u i UK-u te time podložna nacionalnom pravu, ugovorna praksa pokazuje da se često suspendira primjena prava države u kojoj se misija odvija, što dovodi do problema ako ugovor dobije kompanija iz neke druge države koja taj status kontraktora nije pravno regulirala. Rješenje je, naravno, međunarodna regulacija. 
Veliki koraci učinjeni su nedavnom presudom četvorici kontraktora kompanije Blackwater i osnivanjem međunarodne organizacije The International Code of Conduct for Private Security Service Providers Association (ICoC). Ta organizacija donijela je Dokument iz Montreauxa kojim su postavljeni minimalni standardi reguliranja pravnog položaja privatnih kontraktora te zbirka dobre prakse u vanjskom ugovaranju vojnih usluga.

\subsection{Ekonomičnost i efikasnost podugovaranja u resoru obrane}

Nakon dugogodišnje prakse outsourcinga sektora obrane u SAD-u, i dalje ne postoje pouzdani podaci o magnitudi uštede takvog pristupa. Kritizira se da privatni kontraktori mogu biti višestruko skuplji za održavanje nego redovno vojno osoblje (Baum \& McGahan, 2009, str. 4). Međutim, valja navesti sljedeće činjenice koje idu u prilog tome da je takav pristup ekonomičniji za vlade suverenih država. Prvi razlog je što vojska ne mora održavati konstantno visoku brojku zaposlenog vojnog osoblja. Osim toga, privatne vojne kompanije mogu zapošljavati pojedince koji će biti manje plaćeni nego u javnom sektoru. Drugi razlog je što vlade ne moraju omogućiti privatnim vojnim kompanijama beneficije kao što su mirovine, zdravstvena zaštita, objekti za boravak, itd. jer su one najčešće uključene u ugovor. Treći važan razlog je što privatne vojne kompanije omogućavaju brzo povećanje brojnog stanja obrambenih snaga bez troškova za dugoročno održavanje vojnih kapaciteta. Angažmanom privatnog vojnog sektora smanjuje se i mogući broj viška radnika koji napuštaju vojsku uz naknadu, što je česta pojava kada se vojska suočava s naglim redukcijama.

Pri analizi ekonomičnosti vanjskog ugovaranja u sektoru obrane u obzir treba uzeti i sljedeće argumente: a) privatne vojne kompanije obično su plaćene prema stavkama ugovora, a ne po broju raspoređenih vojnika po terenu, pa je teško usporediti njihovu ekonomičnost s ekonomičnošću redovne vojske, b) osoblje privatnih vojnih kompanija često čine pripadnici nacionalnih vojski koji su prošli državnu obuku, a u trenutku napuštanja vojske radi bolje plaćenog posla u privatnom sektoru ta obuka postaje dotacija privatnim vojnim kompanijama i c) stvorene podugovorne prakse u kojima jedan ugovor prolazi kroz nekoliko različitih kompanija može značajno umanjiti dobitke na polju efikasnosti i ekonomičnosti (Baum \& McGahan, 2009, str. 5).

Učinkovitost privatnih kontraktora mnogi autori ističu kao pozitivnu komponentu ovakvog pristupa. Prema nekim analitičarima, privatne vojne kompanije nude operativne prednosti u odnosu prema redovnoj državnoj vojsci iz više 
razloga. Jedan je od njih mogućnost brzog raspoređivanja osoblja koje nije moguće s redovnom vojskom. Nadalje, involviranost privatne komponente nije pod toliko budnim okom javnosti, pa upotreba privatnih kontraktora pridonosi smanjenju zabrinutosti javnosti zbog primjene sile. Dodatna karakteristika je funkcionalnost privatnih kontraktora kao protuteža lokalnoj vojsci u državama sa slabim političkim institucijama (Franke \& Dorff, 2013).

S druge strane, upotreba privatnih kontraktora ima i određene nedostatke. Naime, dvojbena motiviranost privatnih kontraktora zaradom, a ne dužnošću, čini njihovu posvećenost zadatku manjom od one koju ima regularno osoblje. Neki autori upućuju i na suprotan zaključak. Oni u svom zaključivanju idu do te mjere da tvrde da upravo motiviranost zaradom stimulira privatne kontraktora na izvršavanje misija u koje se redovna $\mathrm{dr}$ žavna vojska nikad ne bi upustila (Baum \& McGahan, 2009).

Irak je najbolji primjer svih prednosti i nedostataka outsourcinga sektora obrane. Razlog tome je što on predstavlja najveći angažman privatnog vojnog i sigurnosnog sektora u povijesti međunarodnih aktivnosti u pitanju obnove. Bilo je uključeno više od 60 kompanija koje zapošljavaju više od 20.000 ljudi, koji su svi eksperti za pružanje vojnih i sigurnosnih usluga. Do siječnja 2006. 309 zaposlenika privatnih vojnih kompanija poginulo je u Ira$\mathrm{ku}$, a puno je veća brojka ranjenih. ${ }^{4}$ Strahovit broj umrlih i ranjenih pokazao je još jedan nedostatak koji za sobom povlači privatni vojni sektor. Za razliku od nacionalne redovne vojske, pod velikim pritiskom ili mogućnošću velikih ljudskih i financijskih gubitaka, privatne vojne kompanije imaju tendenciju da se povuku s bojišta. Takvo što možemo vidjeti i prema izvještaju iz 2004. po kojem su, nakon napada na njihov konvoj, vozači kompanije KBR odbili raditi dok se ne popravi njihova sigurnosna situacija. Velik broj njihova osoblja napustio je zemlju, ostavljajući za sobom pripadnike redovne vojske SAD-a bez zaliha hrane i oružja po cijelom teritoriju Iraka (Singer, 2004). Na kraju, specifična je međuovisnost javnog i privatnog sektora. Naime, u posljednjim godinama primijećen je »odljev stručnih vojnih kadrova«. Zbog veće ekonomske isplativosti, pripadnici redovne državne vojske, a pogotovo pripadnici specijalnih postrojbi (npr. Zelene beretke, SAS, Navy Seals, Spetsnaz, Mossad etc.) pokazuju veliku tendenciju selidbe u privatni vojni sektor. U SAD-u to je dovelo do razrade novih platnih, privilegijskih i obrazovnih motivacija za pripadnike specijalnih postrojbi u pokušaju da ih se zadrži. U UK-u razvijen je malo drugačiji pristup borbi protiv privatnog sektora. Oni svojim elitnim vojnicima nude »odmor « u trajanju od godinu dana da bi im omogućili da rade u privatnim vojnim kompanijama u Iraku. 


\subsubsection{Cost-benefit analiza: Usporedba efikasnosti snaga UN-a $i$ privatnib vojnib kompanija na primjeru Angole i Sijera Leonea}

Dobar način za usporedbu efektivnosti i ekonomičnosti konvencionalnih oružanih snaga s privatnim vojnim kompanijama usporedna je analiza troškova misija u Sijera Leoneu i Angoli.

Tablica 3. Usporedba finalnog troška privatnih kontraktora i mirovnih snaga UN-a te potrebnog broja angažiranih ljudi za provođenje identičnib zadataka

\begin{tabular}{|c|c|c|c|c|}
\hline & \multicolumn{2}{|c|}{ SIJERA LEONE } & \multicolumn{2}{|c|}{ ANGOLA } \\
\hline & $\begin{array}{c}\text { Mirovne } \\
\text { snage UN-a }\end{array}$ & $\begin{array}{c}\text { Privatni } \\
\text { kontraktori }\end{array}$ & $\begin{array}{c}\text { Mirovne } \\
\text { snage UN-a }\end{array}$ & $\begin{array}{c}\text { Privatni } \\
\text { kontraktori }\end{array}$ \\
\hline $\begin{array}{l}\text { Ukupni trošak izražen } \\
\text { u američkim dolarima } \\
\text { nasuprot postotnoj } \\
\text { uštedi pri angažiranju } \\
\text { kontraktora }\end{array}$ & $\begin{array}{l}\text { 1,2 milrd. } \\
\text { dolara }\end{array}$ & $\begin{array}{l}\mathbf{9 7 , 9 1 7 \%} \\
\text { niži trošak } \\
\text { za pružene } \\
\text { usluge }\end{array}$ & $\begin{array}{l}626 \text { mil. } \\
\text { dolara }\end{array}$ & $\begin{array}{c}\mathbf{9 0 , 4 1 5 \%} \\
\text { niži trošak } \\
\text { za pružene } \\
\text { usluge }\end{array}$ \\
\hline $\begin{array}{l}\text { Ukupan broj ljudi } \\
\text { angažiran u mirovnoj } \\
\text { misiji nasuprot postotku } \\
\text { angažiranih kontraktora } \\
\text { za istu misiju }\end{array}$ & $\begin{array}{c}11.797 \\
\text { pripad- } \\
\text { nika mirovnih } \\
\text { snaga }\end{array}$ & $\begin{array}{l}\text { 97,033\% } \\
\text { manje } \\
\text { angažiranih } \\
\text { ljudi }\end{array}$ & $\begin{array}{l}7.934 \text { pripad- } \\
\text { nika mirovnih } \\
\text { snaga }\end{array}$ & $\begin{array}{l}\text { 93,068\% } \\
\text { manje } \\
\text { angažiranih } \\
\text { ljudi }\end{array}$ \\
\hline
\end{tabular}

Izvor: Autor, na temelju: Gaul, 1998; v. amplius str. 51 za dodatne statistike i brojke.

U obje misije bile su uključene mirovne snage UN-a (zadužene za stabilizaciju regije) te privatni vojni kontraktori (zaduženi za zaštitu visokih državnih dužnosnika, obuku specijalnih vojnih jedinica za borbu te pomaganje snagama UN-a). Tablica 3 pokazuje da privatne vojne kompanije u usporedbi s UN-ovim mirovnim snagama uspijevaju ostvariti isti cilj s puno manjim financijskim troškovima. Na primjeru misija u Sijera Leoneu i Angoli može se primijetiti da je trošak osoblja privatnih vojnih kompanija puno niži, iako je prosjek pojedinačnih plaća viši od prosjeka plaća pripadnika mirovnih snaga. Upravo je to ključ efikasnosti privatnih vojnih kompanija. U misije se vodi manji broj visoko plaćenih, ali elitnih civilnih kontraktora. Ujedno, privatne vojne kompanije pokazuju veći stupanj mogućnosti okončavanja oružanih konflikata od mirovnih misija UN-a. Razlog tome vidi se u većem stupnju individualne spremnosti za korištenje sile u osjetljivim situacijama. Drugim riječima, »jedini oblik mirovnib misija koji pomaže u okončanju oružanog konflikta onaj je koji 
se temelji na mogućnosti upotrebe sile. Promatrači ili nenaoružani pripadnici mirovnih misija bez vojne podrške pokazuju nizak stupanj pozitivnib efekata na proces pregovaranja izmedu zaraćenih strana ili implementaciju ugovora o primirju.« (Gaul, 1998, str. 52).

\subsubsection{Rezultati ugovorne prakse vanjskog ugovaranja vojnib usluga u SAD-u}

Ugovori o vanjskom ugovaranju usluga iz sektoru obrane problem su sui generis i podloga za mnoge malverzacije od kojih su tek neke otkrivene. Dobar primjer su tzv. »cijena plus« ugovori kojima su kompanije mogle počiniti prijevaru onako kako se to utvrdilo u slučaju Halliburton KBR divizije. Zbog nepotpune dokumentacije, američka vojska dovela je u pitanje oko 1,8 milijardi dolara koje je potraživao Halliburton za rad u Iraku. Za Halliburton, bivšeg poslodavca Dicka Cheneya, navodi se niz sumnji za prijevare koje su se kretale od previsokog naplaćivanja goriva pa sve do sumnji za naplaćivanje nepostojećih usluga. Namjerno ili slučajno, odredene formulacije u takvim ugovorima mogu biti i podloga za počinjenje ratnih zločina bez mogućnosti da se sankcioniraju počinitelji. Tako je bivša prijelazna koalicijska vlada u Iraku davala osoblju pod ugovorom imunitet u odnosu na iračke zakone zbog čega šestoro njih koji su bili umiješani u skandal sa zatvorom u Abu Ghraibu nikada nisu bili izvedeni pred sud (Singer, 2004).

Pitanje lojalnosti i gubitka kontrole nad privatnim kontraktorima problem je svoje vrste. Na problem lojalnosti plaćenika upozoravao je još Machiavelli (Singer, 2008, str. 165). Po modernom shvaćanju, jedna od glavnih situacija koja vodi u gubitak kontrole nad plaćenicima trenutak je kada iznajmljene postrojbe zaključe da mogu ostvariti veći profit ako prijeđu na stranu rivala trenutačnog poslodavca. Spekulacije oko takvog razvoja događaja postoje vezano uz državni udar u Sijera Leoneu 1996. Naime, vjeruje se da je vodstvo privatne vojne kompanije Executive Outcomes znalo za predstojeći državni udar i nije ga prijavilo niti se suprotstavilo pobunjenim snagama, iako je kompanija bila ugovorno obvezana upravo za zaštitu legitimno izabrane vlade od pokušaja državnog udara. Navodni razlog tome je što je tadašnji izvršni odbor Executive Outcomesa vođu pobunjenih snaga vidio kao efektivnijeg u upravljanju državom i kao boljeg partnera za suradnju pro futuro (više o spekulacijama i potencijalnoj pozadini događanja u Sijera Leoneu v. Singer, 2008 i Pelton, 2007).

Od pitanja lojalnosti više zabrinjava tržište privatnih vojnih usluga, odnosno potencijalnih poslodavaca za moderne plaćenike. Osim za države, 
korporacije i međunarodne organizacije, sve je više prijava da privatne vojne kompanije rade za narkokartele i druge oblike organiziranog kriminala. Tako ratni reporter Robert Young Pelton (Pelton, 2007) u svojoj knjizi piše o specifičnoj situaciji u Južnoj Americi, konkretno Kolumbiji. Dok je CIA angažirala dvije američke privatne kompanije u borbi protiv narkokartela, narkokarteli su unajmili kontraktore jedne izraelske privatne vojne kompanije u borbi protiv CIA-e. Također, nije rijetkost da iste privatne vojne kompanije koje pružaju usluge američkom Ministarstvu obrane imaju povijest obučavanja specijalnih vojnih postrojbi za diktatore kao što su Moamar Ghadafi i Saddam Hussein.

\subsection{Praksa vanjskog ugovaranja vojnih usluga u EU-u - britanski i njemački model}

Vanjsko ugovaranje usluga pružanja vojne podrške može se smatrati najdubljom reformom klasičnih resora na području Europe. Početak transformacije klasičnog vođenja resorom obrane slijedi reformske zahvate vlada Margaret Thatcher i Tonyja Blaira u UK-u. Politika privatizacije koju je Margaret Thatcher provodila sredinom 1980-ih prošlog stoljeća obuhvaćala je uz javne službe i privatizaciju divova nacionalne vojne industrije - British Aircraft Corporation, Royal Ordnance, Rolls Royce $i$ Royal Dockyards (Krahmann, 2005, str. 278). Vanjsko ugovaranje širokog spektra vojnih usluga dočekalo je intenzivan početak primjene tek s laburističkom vladom Tonyja Blaira. Jedan od prvih takvih projekata njegove vlade bilo je podugovaranje obuke vojnih pilota za potrebe vojnog kompleksa (Krahmann, 2005., str. 280) Hawk Synthetic Training Facility u Angleseyu 1998. Nedugo nakon tog projekta, uslijedili su novi takve prirode, kao što je sličan ugovor za obuku RAF-ovih pilotskih posada za helikoptere tipa Puma, Chinook i Merlin.

Specifičnost britanskog pristupa vanjskom ugovaranju vojnih usluga u njegovoj je povezanosti s konceptom PFI (Private Finance Initiative) modela. Naime, laburistička vlada Tonyja Blaira predstavila je model PFI kao »prvi izbor za financiranje kapitalnih projekata « britanskog Ministarstva obrane. Model PFI u privatnom vojnom sektoru ima određene značajno drugačije karakteristike od istog modela koji se primjenjuje u sektoru javnih službi. Prvo, britanska vlada poziva privatne kompanije na nadmetanje u javnom natječaju za servisiranje, financiranje, izgradnju i održavanje vojne infrastrukture. Privatni interes u vojnoj inačici modela PFI nije dobivanje novčane naknade, već ugovorna obveza države da odabrane privatne 
partnere zauzvrat nagradi ugovorima o pružanju vojnih usluga čije trajanje iznosi od deset do četrdeset godina (Krahmann, 2005, str. 279). Ti dodatni ugovori stalan su i lukrativan izvor primanja, iako nekad nastaju i »treći izvori« primanja za privatne partnere. Tu je riječ o mogućnosti prodaje viška vojne robe nedržavnim akterima ili drugim državama, ali treba naglasiti da vlada zadržava kontrolu kroz koncept upravljanja putem ugovora i objavljivanjem liste »osjetljivih« lokacija i privatnih entiteta. Trenutačne restrikcije odnose se na aktivnosti povezane s proizvodnjom i razvojem oružja masovnog uništenja te povezanom infrastrukturom. $\mathrm{Na}$ razini EU-a ta zabrana propisana je soft law aktom EU Code of Conduct on Arms Export iz 1998., dok je na razini UK-a regulirana zakonodavstvom o izvozu oružja, odnosno zakonom Export Control Act iz 2002. S protekom vremena i razvojem privatnog vojnog sektora nastali su konzorciji kompanija sa svrhom nadmetanja za projekte britanskog Ministarstva obrane.

Dobar je primjer spomenuti ugovor o obuci RAF-ovih pilota vojnih helikoptera. Odabrani partner za provedbu projekta bio je CSV Aircrew Training, konzorcij sastavljen od kompanija CAE Electronics, Vega i Serco. U tom konkretnom projektu, CAE Electronics dizajnirao je, izgradio i upravljao vojnim kompleksom Medium Support Helicopter Aircraft Training Facility, Vega je imala ulogu opskrbljivača računalnim hardwareom i softwareom za simulatore letenja, dok je Serco bio zadužen za obuku pilota. Može se zaključiti da većinu konzorcija ne vode kompanije iz sektora civilnih usluga, već privatne vojne kompanije koje na taj način ulaze na tržište vojnih usluga. Do 2002. britansko Ministarstvo obrane odobrilo je 42 takva PFI projekta s ukupnom vrijednošću preko 2 milijarde funta, dok je za 2003. bilo u postupku razmatranja 50 novih projekata s procijenjenom vrijednošću od 12 milijardi funta (Krahmann, 2005, str. 279).

Reguliranje profesije plaćenika i civila u području oružanih konflikata dodatna je specifičnost britanskog pristupa. Naime, britanska vlada drži do načela striktne distinkcije između vojne podrške privatnih kontraktora te boraca koji ostaju prerogativ državne vojske. Uzevši u obzir situacije u ratnim zonama, nerijetko dolazi do nepredviđenih situacija i zamjene uloga. Vlada Johna Mayora tome je doskočila uvođenjem koncepta »sponzoriranih rezervnih snaga« 1996.

Taj je koncept inkorporiran u britansko pravo zakonom Reserves Forces Act 1996, točnije odjeljkom V. koji omogućava privatnim kontraktorima uključivanje u oružane konflikte tako da trenutkom ulaženja u oružani konflikt postaju pripadnici dobrovoljnih sponzoriranih rezervnih snaga. Kao dio dobrovoljnih rezervnih snaga postaju dio strukture i zapovjednog lanca britanskih oružanih snaga te sukladno tome podložni vojnom zako- 
nodavstvu, odnosno britanskom zakonodavnom skupu Service Discipline Acts and Service Regulations.

Razmatrajući sve navedeno, regulacija profesije plaćenika i uspostava adekvatnih mehanizama kontrole privatnog vojnog sektora i dalje nije na zadovoljavajućoj razini. To je prepoznala i vlada UK-a koja je kao prvi korak prema boljoj regulaciji objavila publikaciju Green Paper - Private Military Companies: Options for Regulation 2002. U toj publikaciji razmatrane su tri policy opcije za upravljanje privatnim vojnim sektorom: a) nacionalna i međunarodna zabrana plaćeničke profesije, b) nacionalno licenciranje privatnih vojnih kompanija za pružanje usluga i izvoz vojne robe te c) samoregulacija privatne vojne industrije. Prva opcija smatrala se nepovoljnom zbog posljedica za britansku ekonomiju i stanje u nacionalnoj oružanoj sili, dok je trećoj opciji nedostajalo adekvatne kontrole u samo po sebi osjetljivom području. Kao srednji put, vlada UK-a do 2004. implementirala je zakon The Private Security Industry Act 2001 kojim je osnovana državna agencija SIA (Security Industry Authority). Agencija je zadužena za licenciranje privatnih kontraktora, a među kriterije uvrštena je i provjera kaznenog dosjea aplikanata, iako postojanje tog dosjea nužno ne znači odbijanje zahtjeva za licencijom već se opravdanost zahtjeva procjenjuje od slučaja do slučaja (Krahmann, 2005, str. 285).

Zaključno, britanski pristup vanjskog ugovaranja vojnih usluga s privatnim entitetima pristup je utemeljen na upravljanju putem ugovora i regulacije statutarnim pravom. Mora se istaknuti opaska za pristup ugovornom upravljanju kod ugovora koji traju od deset do četrdeset godina. Naime, takva duljina ugovorne obveze dovodi do manjeg stupnja rizika za privatnog partnera, smanjene kvalitete pružanja usluga te skupog plaćanja prijevremenog raskida ugovora od strane države. Takvi raskidi nisu rijetkost i najčešće se događaju sredinom ugovornog razdoblja.

U usporedbi s britanskim modelom upravljanja putem ugovora i pravnih propisa, zanimljiv model upravljanja i kontrole isporuke podugovorenih vojnih usluga predstavlja njemački model. Naime, model o kojemu je riječ negdje je između državnog vlasništva i klasičnog vanjskog ugovaranja. Njemački pristup puno je oprezniji pri puštanju privatnika u resor obrane te se temelji na stvaranju privatnih vojnih kompanija od strane države i zadržavanju određenog vlasničkog udjela u tim poduzećima. Na taj način, umjesto da se nadzor svodi na ispunjenje ugovornih obveza, njemački Bundeswehr ima direktnu kontrolu nad politikom određene kompanije i ostvaruje puno veću razinu nadzora nad zakonitošću djelovanja njezinih zaposlenika.

Uvođenje tržišnih mehanizama u njemački resor obrane počelo je 1994. kad je njemački ministar obrane pokrenuo preoblikovanje strukturnih 
elemenata njemačke obrambene sile i »privatizaciju gdje je ona moguća (Krahmann, 2005, str. 281). Podugovaranje vojnih usluga postaje opcija potpisivanjem Okvirnog dogovora Innovation, Investment and Efficiency in the Bundeswebr između ministra obrane i predstavnika njemačke ekonomije u prosincu 1999. Do 2003. približno 700 privatnih kompanija potpisalo je Okvirni dogovor u sklopu kojeg je identificirano četrnaest projekata koji su varirali od razvoja tehnologije preko vojne obuke do logističke podrške na terenu.

Za razliku od Ujedinjenog Kraljevstva, Njemačka s prvim projektom počinje tek 2001., a praksu manjeg broja projekata nastavlja do danas. Primarna motivacija za držanje veličine privatnog vojnog tržišta pod kontrolom upravo je zaštita temeljnih načela demokracije poštivanje odredbi njemačkog ustava. Prvi ugovor iz 2001. vrijedio je 75 milijuna eura, a svrha projekta bila je obučavanje vojnih pilota u Gefechtsübungszentrum (Vojnom centru za borbenu obranu u Altmarku) za vožnju klasom zrakoplova Eurofighter. Ugovor je vrijedio svega pet godina. Sljedeći projekt potpisan je s drugim privatnicima u sklopu zajedničke privatne kompanije (Krahmann, 2005, str. 282). Razlozi tomu su ovi: kraće ugovorno razdoblje utječe na inicijativu privatnog partnera za podizanjem kvalitete ispunjenja ugovora s ciljem dobivanja novog ugovora i smanjuje se mogućnost za potrebom raskida ugovora kao što je to kod britanskog modela. Specifičnost politike Bundeswebra u tome je što čim nestane potreba za privatnim uslugama, one se zamjenjuju državnim vođenjem. Tako se, na primjeru projekta obuke pilota Eurofightera, novi projekt nije odnosio na daljnju obuku partnera, već se prva generacija pilota Lufwaffea zadržala kao instruktori koji su daljnje generacije obučavali umjesto privatnih kontraktora. Vezano uz kontrolne mehanizme, zanimljiva je jedna od najvećih njemačkih privatnih vojnih kompanija - Gesellschaft für Entwicklung, Beschaffung und Betrieb (Korporacija za razvoj, opskrbu i operacije, GEBB). Naime, iako Bundeswebr nema većinski udio nad vlasništvom dionica, smatralo se da i dalje zadržava pravo na kontrolu i koordinaciju privatnih pružatelja vojnih usluga. Stav da Bundeswebr na taj način ostaje javno odgovoran za operacije privatnih vojnih kompanija potvrđen je presudom suda u Düsseldorfu (Oberlandesgericht Düsseldorf, Verg 67/02, 30. travnja 2003.) u kojoj je utvrdio da čak i kada država nema većinsko vlasništvo nad takvom kompanijom, privatni partneri ostaju u položaju subjekta podložnog uputama javne vlasti.

Zaključno, možemo primijetiti da oba modela imaju svoje prednosti i mane. Kod britanskog modela riječ je o nedovoljnom institucionalnom nadzoru privatnih vojnih kompanija, dok je kod njemačkog pristupa riječ 
o prejakom nadzoru koji usporava jačanje nacionalne ekonomije te razvoj i modernizaciju državne oružane sile. Također, njemački pristup ima učinak samo na teritoriju Njemačke, jer je u slučaju operacija ili vojnih vježbi u drugoj državi većinom važeće strano pravo. Optimalno je rješenje regulacija putem pravnih propisa, no to za razliku od britanskog modela, koji je disperziran, inkonzistentan $\mathrm{i} »$ premlad «, pretpostavlja i međunarodno uređenje u obliku konvencije koja će nametnuti minimalne standarde pravne regulacije tržišta privatnih vojnih kompanija.

\subsection{Hibridni model kao potencijalni model za upravljanje resorom obrane u Republici Hrvatskoj}

Republika Hrvatska nije bila predmetom analize zato što je u skupini rijetkih država EU-a u kojima je vođenje resora obrane inherentno državna funkcija te prema trenutačnim ustavnim ograničenjima nije ni moguć određeni spektar podugovaranja vojnih, a posebno zaštitarskih usluga na terenu. Takva ograničenja proizlaze prvenstveno iz Ustava RH koji predviđa isključivo konvencionalnu vojsku s predsjednikom RH kao vrhovnim zapovjednikom oružanih snaga. Međutim, to ne isključuje da bi se RH mogla u bližoj ili daljoj budućnosti suočiti s proračunskim ograničenjima, zastarjelom tehnologijom ili manjkom profesionalnog kadra, što bi vodilo do nemogućnosti ispunjenja obveza iz članstva u NATO-u ili EU-u. Kao model koji bi Hrvatska mogla u tome slučaju iskoristiti ponajprije se nameće hibridni model koji istovremeno omogućava efektivnu kontrolu nad vojnim osobljem kao i njegovu efikasnost. Razrada takvog modela provedena je kao sinteza dosad analizirane teorije i prakse upotpunjena informacijama dobivenim od relevantnih stručnjaka u provedenom istraživanju.

Istraživanje je provedeno u obliku intervjua s tri relevantna stručnjaka za temu vanjskog ugovaranja vojnih usluga u resoru obrane. Razlog odabira tih osoba njihova je visoka razina upućenosti u temu ovog rada te različitost njihovih profesija, od kojih svaka daje specifičan pogled na problematiku prakse takvog podugovaranja. Svrha tog istraživanja je provjera prethodno u radu iznesenih teorijskih navoda i spoznaja u stvarnom životu.

Istraživanje se sastojalo od niza pitanja koje autor smatra važnima za obradu konkretne teme ovog rada i pravilno formiranje zaključka o njoj. Razgovori su provedeni s doc. Petrom Rodikom (predavačem kolegija vojne sociologije na Katedri sociologije Filozofskog fakulteta Sveučilišta u Zagrebu), brigadirom Sinišom Šimićevim (predavačem na Katedri obrambene politike na Vojnom učilištu »Petar Zrinski«) is Charlesom E. Tuckerom (umirovljenim 
general-bojnikom ratnog zrakoplovstva SAD-a, izvršnim direktorom dviju međunarodnih nevladinih organizacija: World Engagement Institute i Sustainable Capacity International Institute, a opus njegova rada također predstavljaju istraživanja utjecaja mirovnih misija u post-konfliktnim periodima, dok je od posebnog značenja njegova uloga u upravnom odbora ICoCA, asocijacije za nadzor i reguliranje profesije privatnih vojnih kontraktora).

Docent Petar Rodik upućuje na važnost vrijednosti u resoru obrane koje nisu ekonomske naravi. Pravna regulacija privatnih vojnih kontraktora trenutačno je neadekvatna, a sama ekonomičnost njihova djelovanja počinje se dovoditi u pitanje. Također, trenutačno institucionalno uređenje provedbe nadzora nad kontraktorima dovodi do širokog prostora za zloupotrebu njihovih pravno neopravdanih ovlasti. Masakr na trgu Nisoor u Bagdadu, incidenti u Falluji i Abu Ghraibu te nerazjašnjena ubojstva počinjena od CIA-nih kontraktora samo su izdvojeni slučajevi. Brigadir Siniša Šimićev također upozorava na već spomenute pravne problema u regulaciji privatnog vojnog sektora, ali upućuje na pozitivnu stranu primjene infrastrukturnih i intelektualnih javno-privatnih partnerstava. Za razliku od vanjskog ugovaranja usluga, u takvom obliku suradnje distinkcija između uloge civila i predstavnika države ostaje jasna, a korist koju takva suradnja sa sobom nosi podjednako je interesantna privatnom $\mathrm{i}$ javnom partneru. Takav oblik JPP-a mogao bi pronaći primjenu i u RH te pomoći u jeftinijem održavanju i modernizaciji hrvatske oružane sile. Charles E. Tucker napominje da SAD i Velika Britanija već dulje vode politiku takve privatizacije i sada se mogu vidjeti koje su posljedice toga. Ipak, ICoCA je napravila prvi korak u međunarodnoj regulaciji sektora privatnih vojnih usluga spomenutim dokumentom i rješenje problema trebalo bi se vidjeti u izradi konvencije na razini UN-a, na čijem se nacrtu već radi. Jednom kada se uspostave pravni standardi i efektivna kontrola na globalnoj razini, vanjsko ugovaranje vojnih usluga lišeno «pravne stigme» trebalo bi postati standard upravljanja vojnim resorom. Efektivnost i ekonomičnost u stanju potpune uređenosti te materije mogla bi iskoristiti i RH - u obliku hibridnog modela. Uz zadržavanje dijela konvencionalne vojske, drugi dio mogu činiti kontraktori. Bez obveze za subvencijom smještaja, visokim otpremninama, mirovinama, socijalnim i zdravstvenim osiguranjem itsl., takvi kontraktori prvenstveno bi mogli biti korisni u ispunjenju državnih obveza u vidu mirovnih misija UN-a ili čuvanja šengenske granice. Poseban naglasak u tome smislu stavlja se na mornaricu, čiji se zadatci u uvjetima ograničene tehnologije i ljudskih kapaciteta kreću od borbe protiv trgovaca ljudima, švercera različite ilegalne robe do zaustavljanja imigranata. 


\section{Zaključak}

Primjena vanjskog ugovaranja može imati iznimno pozitivne efekte na ekonomičnost i efektivnost javnog upravljanja u resoru obrane. Međutim, treba biti na oprezu i jasno naznačiti da je ekonomičnost samo sredstvo u postizanju krajnjeg cilja - šire društvene koristi i civilizacijskog napretka. Moderna demokratska država zasniva se na vrijednostima koje prelaze okvire ekonomske koristi, a posebno treba paziti na očuvanje standarda demokracije, zaštitu ljudskih prava i provedbu načela zakonitosti. Te vrijednosti dobivaju posebnu važnost kada je riječ o klasičnim državnim resorima kao što je resor obrane.

Analiza je pokazala da vanjsko ugovaranje vojnih usluga, iako visoko efektivno, povlači sa sobom pravnu neopravdanost ovlasti i prava civilnog osoblja te veliku opasnost za očuvanje standarda demokracije. Ako je vanjsko ugovaranje vojnih i zaštitarskih usluga nov način ratovanja, a sigurno je da će žarišta oružanih sukoba u budućnosti imati značajnu komponentu privatnih entiteta, krajnji je trenutak za donošenje pravne regulative u okviru velikih međunarodnih organizacija poput $\mathrm{UN}$-a putem koje bi se na globalnoj razini nametnuli minimalni standardi pružanja vojnih i zaštitarskih usluga, uredile obveze i odgovornosti privatnih kontraktora te - najvažnije - odredila jurisdikcija nad njima. Kroz razgovore sa stručnjacima i analizom povezane materije došlo se do naznake da Republika Hrvatska razmatra primjenu outsourcinga mornarice, odnosno vanjskog ugovaranja usluga upravljanja vojnim brodovima, njihova najma te usluga zaštite nacionalnih voda u cilju borbe protiv trgovaca ljudima, krijumčarenja različite ilegalne robe te zaustavljanja imigranata.

Bude li Republika Hrvatska ozbiljno razmatrala tu opciju, mora biti svjesna nužnosti adekvatnog i pravodobnog uspostavljanja institucionalnog $\mathrm{i}$ normativnog okvira za regulaciju takvog oblika javno-privatne suradnje. Naime, najveći problem je uloga takvih kontraktora u obavljanju funkcija koje su inherentno pripadale samo konvencionalnim vojnim snagama. Prema ilustrativnom svjedočanstvu oca ubijenog devetogodišnjeg dječaka, tijekom suđenja četvorici zaposlenika Blackwatera, u obliku retoričkog pitanja jasno se naznačuje temeljni problem trenutačnog definiranja njihove uloge sljedećom izjavom: »Koja je razlika između njib $i$ terorista?«.

\section{Literatura}

Baum, J. \& McGahan, A. M. (2009). Outsourcing war: The evolution of the Private Military Industry after the Cold War. Toronto, Kanada: Rotman School of 
Management. Preuzeto s mrežne stranice: http://www.business.illinois.edu/ ba/seminars/2009/mcgahan_paper.pdf.

Delmon, J. (2010). Understanding Options for Public-Private Partnerships in infrastructure - Sorting out the forrest from the trees: BOT,DBFO,DCMF, concession, lease. Policy research working paper 5173, The World Bank. Preuzeto s mrežne stranice Svjetske banke: www.openknowledge.worldbank.org/bitstream/handle/10986/19947/WPS5173.pdf? sequence $=1$.

EC-European Comission (2003). Guideliness for Succesfull Public-Private Partnerships. Preuzeto s mrežne stranice Europske. komisije: http://ec.europa.eu/regional_policy/sources/docgener/guides/ppp_en.pdf.

EC-European Comission (2004). Green Paper on Public Private Partnerships and Community Law on Public Contracts and Concessions. Preuzeto s mrežne stranice: http://www.ebrd.com/downloads/legal/concessions/green.pdf.

Franke, C. V., \& Dorff, H. R. (ur.) (2013). Conflict Management and Peacebuilding: Pillars of a New American Grand Strategy. Carlisle, SAD: Strategic Studies Institute and U.S. Army War College Press.

Gaul, M. J. (1998). Regulating the New Privateers: Private Military Service Contracting and The Modern Marque and Reprisal Clause. Loyola Los Angeles Law Review, 31(4), 1489-1522.

Cheung, A. (2009). Public Management Reform in Hong Kong (str. 317-335). U: S. Goldfinch, J. L., Wallis (ur.) International Handbook of Public Management Reform. Cheltenham, UK: Edward Elgar Publishing Limited.

Gulija, B. (2004). Javno-privatno partnerstvo. Euroscope, Bilten Europskog dokumentacijskog centra, 13(73). Preuzeto s mrežne stranice: www.hrcak.srce.hr/ file/53822.

Hinšt, Danijel (2015). Država može vojsku outsourcati - obvezni vojni rok nema smisla. Komentar Jutarnjeg lista, 13. travnja, 2015. Preuzeto s mrežne stranice: http://www.jutarnji.hr/drzava-moze-vojsku-outsourcati--obvezni-vojni-roknema-smisla/1329368/.

Hsu, S.S., \& St. Martin, V. (2015). Four Blackwater guards sentenced in Iraq shootings of 31 unarmed civilians. The Washington Post, April 13, 2015. Preuzeto s mrežne stranice: http://www.washingtonpost.com/local/crime/ four-blackwater-guards-sentenced-in-iraq-shootings-of-31-unarmedcivilians/2015/04/13/55b777e0-dee4-11e4-be40-566e2653afe5_story.html.

Human Rights First (2011) Fact Sheet: „The Case for the Civilian Extraterrial Jurisdiction Act (CEJA)“. Preuzeto s mrežne stranice HRF: https://www.humanrightsfirst.org/wp-content/uploads/pdf/CEJA-Fact-Sheet.pdf.

Krahmann, E. (2005). Private Military Services in the UK and Germany: Between Partnership and Regulation. European Security, 14(2), 277-295.

Markušić, B. (2015). Teorija geneze trgovanja ljudima na području jugoistočne Europe kroz analizu utjecaja militarizacije, političkih procesa i globalne ekonomije. Pravnik, 48(97), 119-143.

Pelton, Y. R. (2007). Licensed to Kill - Hired Guns int be War on the Terror. New York, SAD: Three Rivers Press. 
Poutvaara, P. (2014). Public-sector outsourcing. IZA, World of Labor. Preuzeto s mrežne stranice WOL-a: www.wol.iza.org/articles/public-sector-outsourcing.pdf.

Singer, P.W. (2004). The Private Military Industry and Iraq: What Have We Learned And Where To Next?. Preuzeto s mrežne stranice: www.dcaf.ch/_docs/pp04_ private-military.pdf.

Singer, P.W. (2005). Outsourcing War. Foreign Affairs, March 1, 2015. Preuzeto s mrežne stranice: http://www.foreignaffairs.com/articles/60627/p-w-singer/ outsourcing-war.

Singer, P. W. (2008). Corporate Warriors - The Rise of the Privatized Military Industry. Ithaca and London, SAD: Cornell University Press.

\section{Pravni propisi i sudska praksa}

\section{a) Republika Hrvatska}

Međunarodna konvencija protiv novačenja, korištenja, plaćanja i osposobljavanja plaćenika Ujedinjenih naroda, NN MU - 12/99

Ustav RH, NN 56/90, 135/97, 8/98, 113/00, 124/00, 28/01, 41/01, 55/01, 76/10, $85 / 10$ i $05 / 14$

\section{b) $S A D$}

Estate of Himoud Saed Atban et al. v. Blackwater USA et al. (07-1831)

Alien Tort Claims Act of 1789 (28 U.S. Code $§ 1350$ )

Civilian Extraterritorial Jurisdiction Act of 2011 (18 U.S. Code 1145)

Genocide Victims of Krajina v. L-3 Communications Corp. and MPRI Inc. (10cv-05197)

Military Extraterritorial Jurisdiction Act ( 18 U.S. Code $§ 212$ )

c) Njemačka

Oberlandesgericht Düsseldorf, Verg 67/02, 30. travnja 2003. 


\section{OUTSOURCING IN THE DEFENCE SECTOR}

\section{Summary}

The use of outsourcing in the defence sector represents a current trend of running the state defence policy and a relatively new phenomenon in the governance of most countries outside the Anglo-Saxon area of influence. The paper analyses the economic and legal aspects of a wide range of public-private partnerships in the defence sector in search of an answer to the question of the real level of cost-effectiveness and efficiency of such an approach on the one hand, and legal justification and possible implications for the standards of democracy on the other. To find the answers to these questions, the analysis begins with a general conceptual definition of outsourcing on the PPP scale, a review of the models of cooperation between the private and the public sector accompanied by practical examples, and the legal regulation of this type of cooperation at EU level. The general overview of the practice of outsourcing is primarily based on the example of the United States, with an emphasis on the typology and a brief historical overview of the private military sector. This is followed by a cost-benefit analysis of outsourcing military services to private actors. The legal analysis is equally important because of a mostly uneven and often non-existent legal framework that would regulate private military companies. The author uses a global approach and analyses the application of private contractors in peacekeeping and military missions by reviewing the models found in the USA, the UK and Germany. The final confirmation of the thesis that the outsourcing of military services to private actors is effective, but insufficiently regulated from a legal point of view, is based on a case study analysis and interviews with relevant experts.

Keywords: outsourcing, public-private partnerships, private military corporations, private security corporations, PMCs, UN, Montreux Document 